\title{
HOMEOSTASIS REGULATING FACTORS, INNERVATION, ISCHEMIA AND INFLAMMATORY MARKERS IN THE RIGHT ATRIAL TISSUE FROM PATIENTS WITH DEGENERATIVE AORTIC VALVE STENOSIS AND CORONARY HEART DISEASE
}

\author{
Edīte Vārtiṇa ${ }^{1}$, Māra Pilmane ${ }^{2}$, and Romāns Lācis ${ }^{1}$ \\ ${ }^{1}$ Pauls Stradinš Clinical University Hospital, 13 Pilsoṇu Str., Rīga, LV-1002, LATVIA \\ ${ }^{2}$ Rīga Stradiṇš University, Rīga, Latvia, 16 Dzirciema Str., Rīga, LV-1007, LATVIA \\ Corresponding author, edite.vartina@stradini.Iv
}

Contributed by Māra Pilmane

\begin{abstract}
Both coronary heart disease (CHD) and degenerative aortic valve (AoV) stenosis have common risk factors, such as age, high blood cholesterol, diabetes, smoking, high blood pressure, inflammation, and metabolic syndrome. However, these diseases are not always observed together, confirming the existence of risk and pathogenesis factors specific to each disease. The aim of this study was to identify presence and distribution of common and different homeostasis regulating factors, innervation, ischemia and inflammatory markers in the right atrial tissue from patients with degenerative AoV stenosis and CHD. During elective cardiac surgery, right atrial tissue fragments were taken from 20 patients with $\mathrm{CHD}$ and from 9 patients with degenerative AoV stenosis. All tissue fragments were stained for immunohistochemical detection of protein-gene peptide 9.5 (PGP 9.5), atrial natriuretic peptide (ANUP), vascular endothelial growth factor (VEGF), chromogranin $A$, endothelin, interleukin 1 and 10 (II-1 and II-10) and $\beta$ defensins 2 , and 3 ( $\beta D 2$ and $\beta D 3$ ). For the quantification of structures, a semi-quantitative counting method was used. Mostly numerous II-10 positive cardiomyocytes and epi-/endocardial endothelial cells were detected in all specimens taken from patients with $C H D$, and statistically more than in specimens taken from patients with degenerative AoV disease $(p=0.007$ and $p=0.016)$. Also, the number of $\beta D 3$ positive cardiomyocytes was higher in the coronary heart disease group $(p=0.026)$. All other tested markers such as PGP 9.5, ANUP, VEGF, endothelin, chromogranin A, II-1 and $\beta D 2$ showed similar expression in both groups. Increased production of ANUP in right atrial tissue characterises both CHD and degenerative AoV stenosis. Production of ChgA in right atrial endocardial endothelial cells might represent regulation of sympathetic activity as a compensatory homeostatic response. Increased PGP 9.5-containing innervation is characteristic in patients with degenerative AoV disease and secondary mitral insufficiency. A stable increase of VEGF and variations of endothelin without statistically significant difference suggest influence of ischemia on the local vascular blood supply. Decreased production of II-1 $\alpha$ together with moderate to rich production of $11-10, \beta D 2$, and $\beta D 3$ indicates the dominance of the local immune system over inflammation.
\end{abstract}

Key words: protein-gene peptide 9.5, atrial natriuretic peptide, vascular endothelial growth factor, chromogranin A, endothelin, interleukin 1 and 10, and $\beta$ defensins 2, and 3.

\section{INTRODUCTION}

Diseases of the heart and circulatory system are the leading cause of mortality in Europe, responsible for over 3.9 million deaths a year (Wilkins et al., 2017). One of the main forms of cardiovascular diseases is coronary heart disease (CHD), and it is the most common single cause of death in Europe, accounting for $19 \%$ of all deaths among men and $20 \%$ among women each year (Wilkins et al., 2017). 
Degenerative aortic valve (AoV) stenosis is the most frequent native valve disease (Iung et al., 2003), and it has become the most common indication for valve surgery as well as catheter intervention for structural heart disease (Baumgartner and Walther, 2018).

Both CHD and degenerative AoV stenosis have common risk factors such as age, high blood cholesterol, diabetes, smoking, high blood pressure, inflammation, and metabolic syndrome. CHD is present in $30 \%$ of patients with mild to moderate AoV stenosis and $50 \%$ with critical AoV stenosis (Baumgartner and Walther, 2018). Since these diseases are not always observed together, risk and pathogenesis factors specific to each disease exist.

Important factors for the pathogenesis of the above mentioned diseases are: homeostasis regulating factors, innervation, and inflammation. Atrial natriuretic peptide (ANUP) works as a homeostasis regulating factor and is stored in atrial cardiomyocytes, released in response to stretch and act on kidney and peripheral circulation to unload the heart, through increased excretion of sodium and water, while inhibiting the release of renin and aldosterone (Tanai and Frantz, 2016). Neurosecretory protein chromogranin A (ChgA) is co-stored and co-released in atrial cardiomyocytes together with ANUP (Angelone et al., 2012). ChgA serum levels are increased in patients with chronic heart failure and are a predictive factor for mortality (Ceconi et al., 2002).

Protein gene peptide 9.5 (PGP 9.5) is a significant marker for the visualisation of neuropeptide-containing innervation. PGP 9.5 is a neuronal marker and has been proposed as a reliable marker for visualisation of the cardiovascular system innervation (Chow et al., 2001).

Vascular endothelial growth factor (VEGF) is one of the most common ischemia markers. It is produced by a variety of adult tissues and vascular and inflammatory cells. VEGF in both physiologic and pathologic conditions induces endothelial cell migration, proliferation, and sprouting and results in angiogenesis and it is essential for embryonic vascular development (Dashkevich et al., 2013).

Endothelin is primarily secreted by endothelial cells (Davenport et al., 2016); it is a potent vasoconstrictor and has other important effects in the heart, including stimulation of myocyte hypertrophy and atrial natriuretic peptide secretion from myocytes (Shubeita et al., 1990; Molenaar et al., 1993). Endothelin plays an important role in endothelial dysfunction (Bonetti et al., 2003), which contributes to atherogenesis at every phase of atherosclerosis (Matsuzawa and Lerman, 2015).

Interleukin $1 \alpha(\mathrm{Il}-1 \alpha)$ and interleukin 10 (Il-10) are the main inflammatory and anti-inflammatory cytokines. Il-1 $\alpha$ is a cytokine that regulates immune responses and inflammatory reactions (Di Paolo and Shayakhmetov, 2016), but Il-10 is an anti-inflammatory cytokine and all its bioactivity results in a suppression of immune responses (Mosser and Xia, 2009).
The $\beta$ defensins 2 and 3 are antimicrobial peptides of which $\beta \mathrm{D} 2$ possesses microbicidial activity against Gram-negative bacteria and yeasts (Schröder and Harder, 1999), but $\beta D 3$ in contrast to $\beta \mathrm{D} 2$ has microbicidial activity also against Gram-positive bacteria, including multi-resistant strains (Dhople et al., 2006).

The aim of our study was to identify the presence and distribution of homeostasis regulating factors, innervation, ischemia and inflammatory markers in the right atrial tissue from patients with degenerative AoV stenosis and CHD.

\section{MATERIALS AND METHODS}

During the elective open heart surgery, atrial tissue fragments were taken from 20 patients with CHD and from 9 patients with degenerative AoV stenosis.

The reported research activities are consistent with the ethical requirements of Rīga Stradiňš University (Ethics Committee meeting date 29.05.2014). All tissue specimens were obtained with informed consent.

All patients were examined as usual before elective cardiac surgery; they underwent transthoracic echocardiography, coronary angiography, and analysis of complete blood count, blood biochemistry (C-reactive protein (CRP), brain natriuretic peptide (BNP), cholesterol fractions including low-density lipoprotein cholesterol (LDL) and high-density lipoprotein cholesterol (HDL). The primary preoperative data are shown in Table 1. The mean age (mean \pm SD) in the CHD group was $65.4 \pm 9.6$, and $70.7 \pm 8.8$ in the AoV group. Thirteen patients (65\%) in the CHD group and eight patients $(88.9 \%)$ in the AoV group had good left ventricular systolic function (left ventricular ejection fraction more than $55 \%$ ). $95 \%$ of patients in the CHD group and all patients in the AoV group had either none or mild secondary mitral regurgitation. None of the patients in both groups had moderate or severe tricuspid regurgitation. Five patients in the CHD group and two patients in the AoV group had a history of diabetes mellitus. $75 \%$ of patients in the CHD group received statin therapy before surgery and the mean LDL level was $2.0 \pm 1.2 \mathrm{mmol} / \mathrm{l} ; 55.6 \%$ of patients in the AoV group received statin therapy before surgery and the mean LDL level was $2.3 \pm 1.0 \mathrm{mmol} / \mathrm{l}$ and there were no significant difference between both groups $(p=0.075)$.

Tissue fragments $\left(\sim 2 \mathrm{~mm}^{2}\right)$ were taken from the venous cannula insertion site before cardiopulmonary bypass was started and the cardioplegic solution was given. Tissue fixation was carried out immediately in the operating room, and for this purpose we used previously prepared Eppendorf tubes with saturated picric acid solution ( $2 \%$ formaldehyde and $0.2 \%$ picric acid in $0.1 \mathrm{M}$ phosphate buffer $(\mathrm{pH} 7.2)$ ). Tissue fragments were transported to a morphology laboratory at the Institute of Anatomy and Anthropology, Rīga Stradiňš University. Tissue fragments were washed for 12 hours in $10 \%$ sucrose phosphate buffer, embedded in paraffin and cut into $8 \mu \mathrm{m}$ thick slices. 
Table 1. Preoperative data of patients

\begin{tabular}{|c|c|c|c|c|}
\hline & & $\begin{array}{c}\text { CHD Group } \\
\mathrm{n}=20(\%)\end{array}$ & $\begin{array}{c}\text { AoV Group } \\
\mathrm{n}=9(\%)\end{array}$ & $p$ \\
\hline Male, n (\%) & & $15(75.0)$ & $3(33.3)$ & \\
\hline Age, mean $\pm \mathrm{SD}$ & & $65.4 \pm 9.6$ & $70.7 \pm 8.8$ & 0.232 \\
\hline Diabetes Mellitus, n (\%) & & $5(25.0)$ & $2(22.2)$ & \\
\hline Use of statins, n (\%) & & $15(75.0)$ & $5(55.6)$ & \\
\hline \multicolumn{5}{|l|}{ Cholesterol, mmol/l } \\
\hline & $\mathrm{LDL}$, mean $\pm \mathrm{SD}$ & $2.0 \pm 1.2$ & $2.3 \pm 1.0$ & 0.524 \\
\hline & $\mathrm{HDL}$, mean $\pm \mathrm{SD}$ & $1.0 \pm 0.2$ & $1.4 \pm 1.5$ & 0.075 \\
\hline $\mathrm{CRP}, \mathrm{mg} / \mathrm{l}$ & & $6.9 \pm 11.1$ & $2.4 \pm 3.9$ & 0.169 \\
\hline $\mathrm{BNP}, \mathrm{pg} / \mathrm{ml}$ & & $326 \pm 326$ & $109 \pm 3$ & 0.137 \\
\hline \multicolumn{5}{|l|}{ LVEF, \% } \\
\hline & $55, \mathrm{n}(\%)$ & $13(65)$ & $8(88.9)$ & \\
\hline & $<39^{\prime}, \mathrm{n}(\%)$ & $1(5)$ & $0(0)$ & \\
\hline \multicolumn{5}{|l|}{ MR } \\
\hline & 0 & $3(15)$ & $1(11.1)$ & \\
\hline & $0-\mathrm{I}$ & $1(5)$ & $1(11.1)$ & \\
\hline & I & $11(55)$ & $4(44.4)$ & \\
\hline & $\mathrm{I}-\mathrm{II}$ & $2(10)$ & $2(22.2)$ & \\
\hline & II & $2(10)$ & $1(11.1)$ & \\
\hline & III-IV & $1(5)$ & $0(0)$ & \\
\hline \multicolumn{5}{|l|}{ TR } \\
\hline & 0 & $1(5)$ & $0(0)$ & \\
\hline & $0-\mathrm{I}$ & $7(35)$ & $4(44.4)$ & \\
\hline & I & $10(50)$ & $5(55.6)$ & \\
\hline & I-II & $1(5)$ & $0(0)$ & \\
\hline \multicolumn{5}{|l|}{ RAA, $\mathrm{cm}^{2}$} \\
\hline & & $17(85)$ & $8(88.9)$ & \\
\hline & 18 & $3(15)$ & $1(11.1)$ & \\
\hline
\end{tabular}

CRP, C reactive protein; HDL, high-density lipoprotein; LDL, low-density lipoprotein; LVEF, left ventricular ejection fraction; MR, mitral regurgitation; RAA, right atrial area; TR, tricuspid regurgitation.

Tissues for routine light-microscopical examination were stained with haematoxylin and eosin.

All tissue fragments were stained for immunohistochemical detection of the following:

- Protein-gene peptide 9.5 (439273A, working dilution 1 : 200, Invitrogen, USA).

- Human atrial natriuretic peptide (8515/6, working dilution 1 : 10, Dako, Denmark).

- Chromogranin A (910216A, working dilution 1: 100, Invitrogen, USA).

- Vascular endothelial growth factor (SC7269, working dilution 1 : 50, Santa Crus Biotechnology, Inc., USA).

- Endothelin (ab2786, working dilution 1 : 250, Abcam, England).

- Interleukin $1 \alpha$ (sc-9983, working dilution 1 : 50, Santa Cruz Biotechnology, Inc., USA)
- Interleukin 10 (ab34843, working dilution 1: 400, Abcam, England)

- $\beta$ defensin 2 (AF2758, working dilution $1: 100$, R\&D Systems, Germany)

- $\beta$ defensin 3 (orb183268, working dilution 1 : 100, Biorbyt, UK)

For negative controls the primary antibody was replaced by a diluent. Positive controls (in tissues which always have positive reaction) were prepared for each preparation series as well.

To assess the cellular structure, all specimens were observed using a Leica VM 6000B microscope.

For the quantification of structures, a semiquantitative counting method was used. The designations were as follows: 0 - negative reaction; $0 /+-$ occasional positive structures in the view field; +- a few positive structures in the view field; $+/++-$ few to a moderate number of positive structures in the view field; ++- moderate count of positive 
structures in the view field; ++ / +++ - moderate to great number of positive structures in the view field; +++ - numerous positive structures in the view field; ++++ - abundance of positive structures in the view field (Pilmane et al., 1998).

All statistical analyses were performed with IBM SPSS Statistics 22. To determine the differences of distribution of different variables between groups, we used the MannWhitney U test. The Spearman's rank-order correlation test was used to determine the relationship between variables. Statistical significance was considered at the level of $p<$ 0.05 .

\section{RESULTS}

There was vacuolar degeneration of cardiomyocytes in both groups; however, it was more pronounced and more specific to right atrial tissue taken from patients with CHD. Invasion of connective tissue and vascular sclerosis was characteristic for both groups as well. Surprisingly, small vessel sclerosis was found even in the right atrial tissue fragments taken from patients with AoV stenosis and without significant lesions in coronary arteries (verified by coronary angiography before surgery) (Fig. 1).

Expression of ANUP varied from moderate number to numerous positive cells in the view field in both groups without significant differences. There was very strong correlation between the number of ANUP-positive cardiomyocytes and the level of brain natriuretic peptide (BNP) in patient's blood test $\left(\mathrm{r}_{\mathrm{s}}=0.822 ; p=0.012\right)$.

In both the CHD group and the AoV stenosis group there were specimens with negative reaction to ChgA as well as specimens with abundance of ChgA positive endotheliocytes in the view field. Some specimens (in both groups) had cube-shaped endocardial cells that were positive to ChgA (Fig. 2).

Almost all examined specimens showed mainly numerous PGP 9.5-containing nerves and there was no significant difference between the two groups (Fig. 3). There was very strong statistically significant correlation between the amount of PGP 9.5-positive nerve fibres in right atrial tissue in the degenerative AoV stenosis group and the grade of preoperative MR $\left(r_{\mathrm{s}}=0.841 ; p=0.004\right)$, but no significant correlation with the grade of preoperative TR $\left(r_{s}=0.185\right.$; $p=0.633)$.

The expression of VEGF and endothelin in the right atrial vascular endothelial cells varied from absence to abundance of positive structures in the view field, with a slight predominance in specimens taken from patients with coronary heart disease. Although there were more endothelin and VEGF positive endocardial and vascular endothelial cells in right atrial tissue from patients with $\mathrm{CHD}$, the difference did not reach statistical significance $(p>0.05)$. There were no statistical differences of distribution of number of endothelin positive vascular or endocardial endothelial cells be- tween male and female patients, neither in all specimens nor in groups $(p>0.05)$.

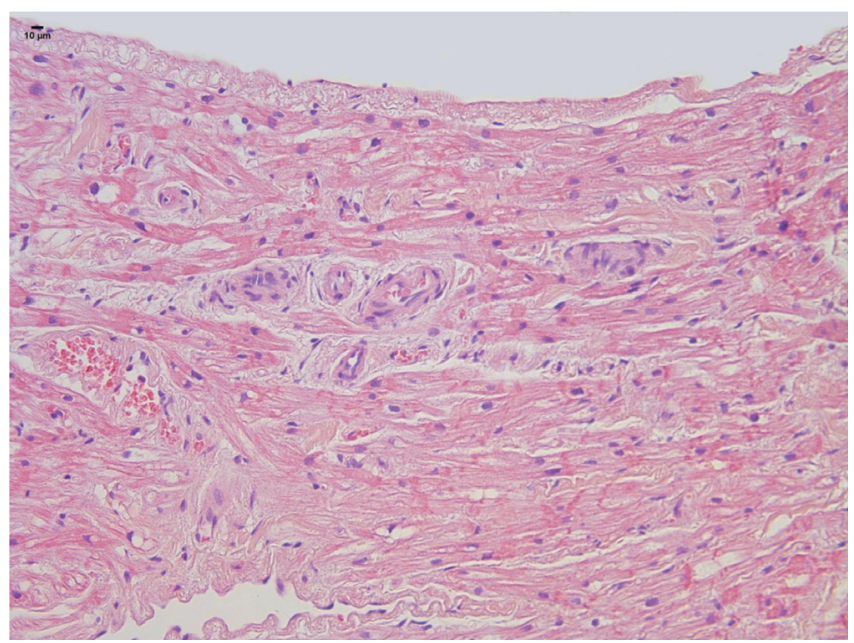

Fig. 1. Almost completely sclerotised arterioles in right atrial myocardium from a patient with degenerative aortic valve stenosis and no significant lesions in coronary angiogram $(\mathrm{H} / \mathrm{E}, \times 200)$.

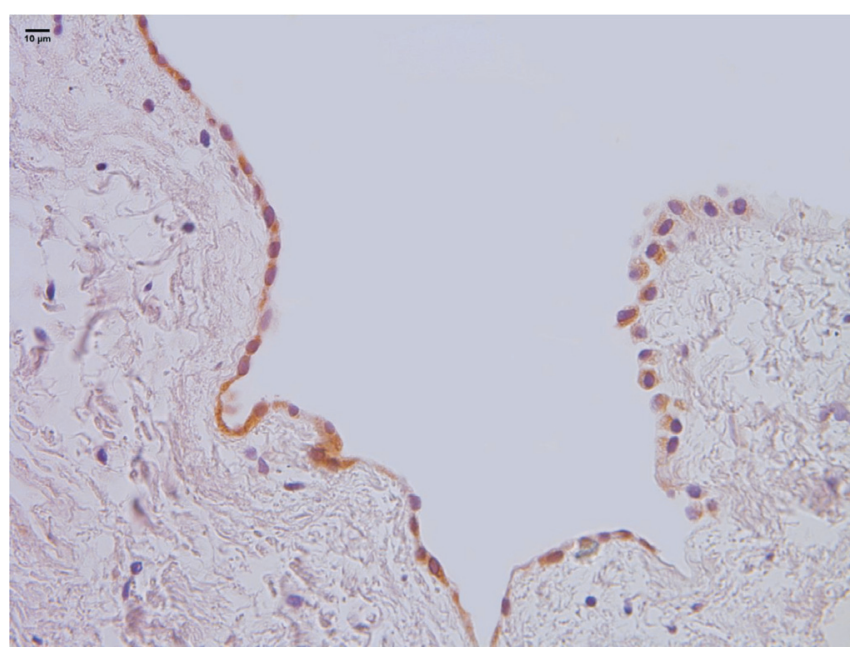

Fig. 2. Numerous chromogranin A (ChgA) positive endocardial endothelial cells in right atrial tissue from a patient with coronary heart disease (ChgA IMH, $\times 250$ ).

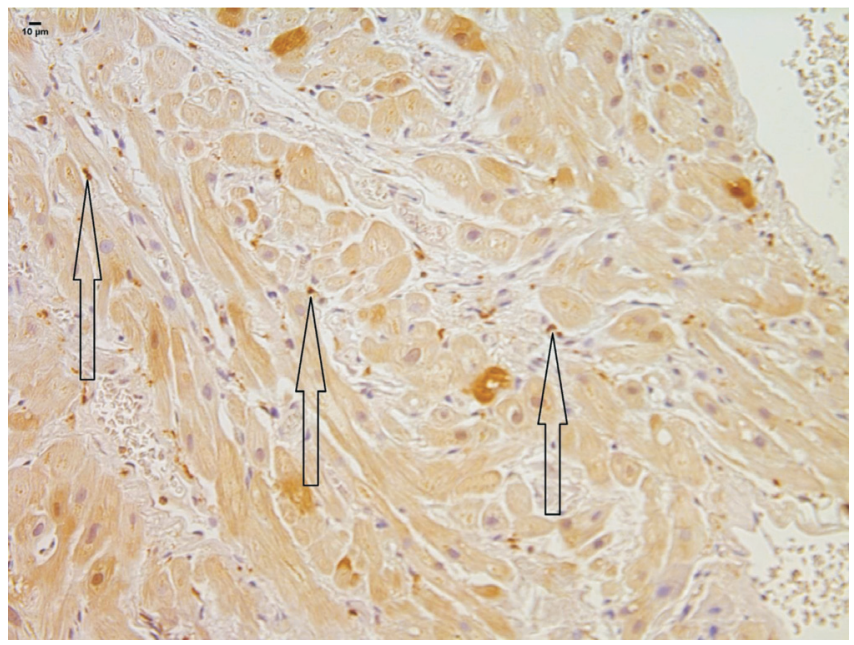

Fig. 3. Numerous protein-gene peptide (PGP) 9.5 containing nerve fibers in right atrial myocardium from a patient with coronary heart disease (arrows, PGP 9.5, IMH, ×200). 
A few to moderate number of interleukin $1 \alpha$-positive cells were found in all specimens. In both groups, a moderate to great number of Il-10-, $\beta$ D2-, and $\beta$ D3-positive cardiomyocytes, connective tissue, endothelial cells, and endocardial

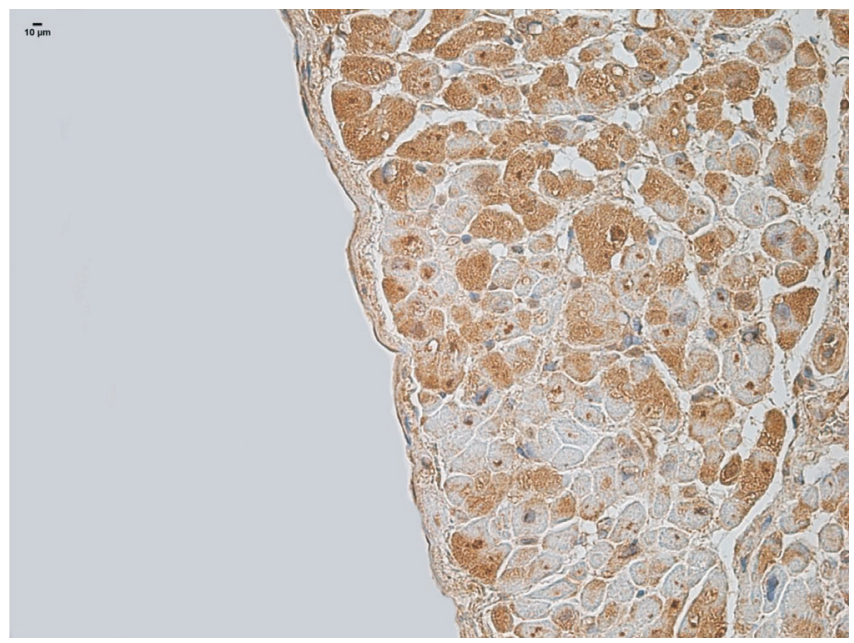

Fig. 4. Numerous interleukin 10 positive cardiomyocytes in right atrial tissue from a patient with degenerative aortic valve stenosis (Il-10 IMH, $\times 250)$.

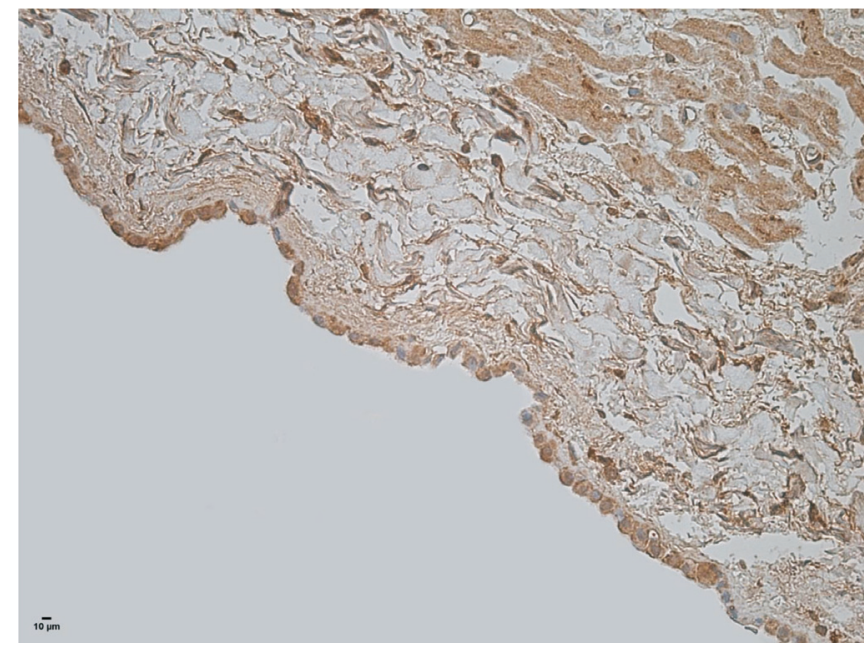

Fig. 5. Numerous interleukin 10 positive endocardial endothelial cells in right atrial tissue from a patient with coronary heart disease (Il-10 IMH,

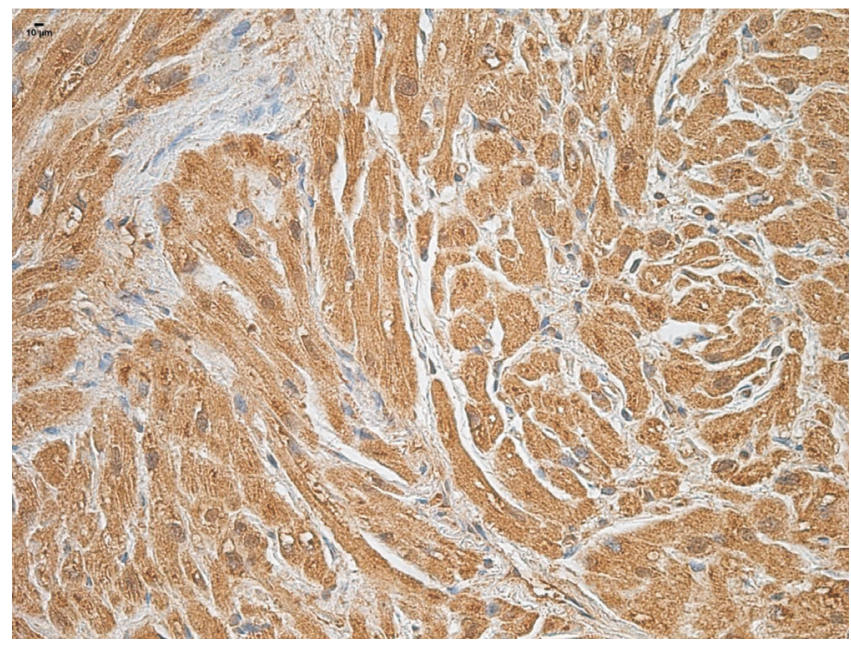

Fig. 6. Abundance of $\beta \mathrm{D} 3$-positive cardiomyocytes in right atrial tissue from a patient with coronary heart disease $(\beta \mathrm{D} 3 \mathrm{IMH}, \times 250)$. and epicardial cells were detected. There was moderate to great number of interleukin 10 positive cardiomyocytes (Fig. 4) and endocardial endothelial cells in right atrial tissue from patients with degenerative AoV stenosis, but in right atrial tissue from patients with CHD, Il-10 positive cardiomyocytes and endocardial endothelial cells were mostly numerous (Fig. 5) and the differences were statistically significant $(p=0.007$ and $p=0.016)$. As well as for Il-10, also the expression of $\beta \mathrm{D} 3$ was different between two groups - there were more $\beta \mathrm{D} 3$-positive cardiomyocytes (Fig. 6) in specimens taken from patients with CHD ( $p=$ $0.004)$.

\section{DISCUSSION}

There are similar opinions about the close relationship between atherosclerosis risk factors and degenerative AoV stenosis ( Stewart et al., 1997; Agmon et al., 2001; Allison et al., 2006). Nevertheless, prevalence of significant CHD in patients with degenerative AoV disease varies from $40 \%$ to more than $65 \%$, and increases with age (Goel et al., 2013). Cellular and molecular changes in degenerative AoV cusps have been described from the early disease process (Otto et al., 1994) till the end-stage disease (Isner et al., 1990), and at least early lesions of aortic valve sclerosis resemble arterial atherosclerotic plaques (Agmon et al., 2001). In our study, we examined the right atrial tissue, which is one of the least involved heart tissues in the direct pathogenesis of degenerative AoV stenosis.

There were no healthy right atrial tissues among the specimens we reviewed. Even in the degenerative AoV stenosis group, we observed vacuolar degeneration of the right atrial cardiomyocytes, and ingrowth of connective tissue and small vessel sclerosis, despite the fact that this group had an absence of significant coronary artery disease in angiography. From the above we can speculate that degenerative AoV stenosis is a disease of the whole heart, not a disease of the left heart or even just a disease of aortic valve cusps.

ANUP and BNP are secreted into circulation under the same condition - in response to stretching of the myocardium (Nakagawa et al., 2019); therefore, there was very strong correlation between the number of ANUP-positive cells and the plasma BNP level in our study. Ventricular BNP gene expression is upregulated by myocardial hypoxia, resulting in elevated plasma concentrations in patients with stable coronary disease and normal or almost normal ventricular function (Goetze et al., 2003). In our study, moderate number to numerous ANUP-positive cardiomyocytes in the view field were characteristic for both groups, even in patients with a preserved left ventricular ejection fraction and no signs of congestive heart failure. Thus, our observations might suggest that ANUP secretion, and also BNP secretion, are increased in patients with stable coronary disease and without congestive heart failure.

Cardiac ChgA is co-stored in atrial granules together with natriuretic peptides (Goetze at al., 2013). Similar to natri- 
uretic peptides, increased ChgA plasma concentrations are associated with clinical deterioration - long-term mortality, re-admission to hospital for heart failure and recurrent myocardial infarction, in patients with acute coronary syndrome and chronic heart failure (Goetze et al., 2013). There were some specimens with ChgA positive cube shaped endocardial endothelial cells in both groups. Presence of factor in endocardium suggests that human heart endocardial endothelial cells might change phenotype and produce neuroendocrine hormones for tissue remodelation. Since ChgA represents overall sympathetic activity (Tota et al., 2014), its production might be a compensatory homeostatic response.

Both groups showed rich PGP 9.5-containing innervation, but only the AoV stenosis group showed very strong correlation between the amount of PGP 9.5-positive nerve fibres in right atrial tissue in degenerative AoV stenosis group and the grade of preoperative MR. Functional MR in patients with severe AoV stenosis may be the result of increased left ventricular afterload due to aortic valve obstruction and left ventricular remodelling (Sahinarslan et al., 2016). Thus, increased PGP 9.5-containing innervation may be a part of compensatory remodelling. Interestingly, we did not observe a similar increase of PGP 9.5-containig innervation in patients with AoV stenosis and secondary tricuspid valve insufficiency, likely because it is frequently a manifestation of right ventricular failure due to left-sided valve disease (Jeong et al., 2014).

If altered PGP 9.5-containing innervation in the right atrium in patients with decompensated AoV stenosis (with secondary mitral valve insufficiency) is observed, then it is possible that innervation changes may also be seen in the left side of the heart. Heterogeneous hyperinnervation increases the risk of malignant arrhythmias and sudden cardiac death, so it is very important to find visualisation methods of cardiac innervation that can be used in clinical practice to predict the risk of arrhythmias and choose the appropriate treatment method (Huanget et al., 2017; Travin, 2017). Atrial and ventricular arrhythmias and sudden cardiac death are common in patients with symptomatic AoV stenosis (Kanwar et al., 2018). To evaluate the cardiac innervation visualisation methods available in clinical practice, it is important to understand the innervation changes in various heart diseases. Therefore, additional studies are needed to evaluate the innervation changes of the left side of the heart in patients with aortic valve stenosis.VEGF is upregulated under hypoxic conditions through hypoxia-inducible factors (Zimna et al., 2015). This is also confirmed by our findings; patients with coronary heart disease showed higher expression of VEGF, although the differences did not reach statistical significance in either vascular endothelial cells or endocardial endothelial cells.

In our study, the same as for VEGF, also expression of endothelin varied from absence to abundance of positive structures in the view field, without significant difference between both groups and by gender. Circulating endothelin levels have been shown to increase in women with CHD
(Daka et al., 2015), and they predict cerebrovascular and cardiovascular events (Novo et al., 2014); however, the plasma endothelin concentration can be significantly decreased by regular exercising (Maeda et al., 2003).

Inflammation is a risk factor for both CHD (Bakerman et al., 2018) and degenerative AoV stenosis (Akahori et al., 2018). Our finding of moderate to high expression of Il-10, $\beta \mathrm{D} 2$, and $\beta \mathrm{D} 3$ in cardiomyocytes, connective tissue, endothelial cells, and endocardial and epicardial cells in both CHD group and degenerative AoV stenosis group confirms the so-called inflammatory hypothesis. The expression of beta defensins is typically upregulated by pro-inflammatory cytokines and by exposure to bacteria (Selsted and Ouellette, 2005). While there was significantly more $\beta \mathrm{D} 3$-positive cardiomyocytes in specimens taken from patients with CHD, it should be noted that in the degenerative AoV stenosis group, high expression of inflammatory markers was found in right atrial tissue, reaffirming that this is not only a local problem of aortic valve cusps (Lindman et al., 2016).

There was a higher expression of anti-inflammatory cytokine Il-10 in cardiomyocytes and endocardial endothelial cells in specimens taken from patients with coronary heart disease than in specimens taken from patients with degenerative AoV stenosis. Il-10 has not only anti-inflammatory, but also anti- and pro-fibrotic effect (Sziksz et al., 2015; Cihakova, 2018). Hulsmans et al. (2018) showed that macrophage-specific Il-10 deletion reduces myocardial fibrosis and improves diastolic function (Hulsmans et al., 2018). This could be one of the reasons why right atrial myocardial fibrosis was observed in all specimens.

\section{CONCLUSIONS}

Increased production of ANUP in right atrial tissue characterises both coronary heart disease and degenerative aortic valve stenosis and may be a sign of congestive heart failure, even without clinical symptoms.

ChgA is not specific to any of the investigated tissues from patients with atherosclerotic diseases. Presence of ChgA and changed shape of endocardial endothelial cells suggests the idea about possibility of human heart endocardial endothelial cells to change phenotype and produce neuroendocrine hormones for regulation of sympathetic activity as a compensatory homeostatic response.

Rich PGP 9.5-containing innervation is characteristic for both $\mathrm{CHD}$ and degenerative AoV disease. Increased PGP 9.5-containing innervation is characteristic in patients with degenerative AoV disease and secondary mitral insufficiency.

Stable increase of VEGF and variations of endothelin without statistically significant difference suggests influence of ischemia on the local vascular blood supply. 
Decreased production of Il- $1 \alpha$ together with moderate to rich production of $11-10, \beta \mathrm{D} 2$, and $\beta \mathrm{D} 3$ indicates the dominance of the local immune system over inflammation.

\section{REFERENCES}

Agmon, Y., Khandheria, B. K., Meissner, I., Sicks, J. R. D., O'Fallon, W. M., Wiebers, D. O., Whisnant, J. P., Seward, J. B., Tajik, A. J. (2001). Aortic valve sclerosis and aortic atherosclerosis: Different manifestations of the same disease? Insights from a population-based study. J. Amer. Coll. Cardiol., 38 (3), 827-834.

Akahori, H., Tsujino, T., Masuyama, T., Ishihara, M. (2018). Mechanisms of aortic stenosis. J. Cardiol., 71 (3), 215-220.

Allison, M. A., Cheung, P., Criqui, M. H., Langer, R. D., Wright, C. M. (2006). Mitral and aortic annular calcification are highly associated with systemic calcified atherosclerosis. Circulation, 113 (6), 861-866.

Angelone, T., Mazza, R., C. Cerra, M. (2012). Chromogranin-A: A multifaceted cardiovascular role in health and disease. Curr. Med. Chem., 19 (24), $4042-4050$.

Bakerman, I., Mirwais, W., Nguyen, P. (2018). Molecular imaging of inflammation in ischemic heart disease. Curr. Cardiovasc. Imaging Rep., 11 (6), 13.

Baumgartner, H., Walther, T. (2018). Aortic stenosis. In: The ESC Textbook of Cardiovascular Medicine. 3rd ed.

https://doi.org/10.1093/med/9780198784906.001.0001 (accessed 10.05.2021).

Bonetti, P. O., Lerman, L. O., Lerman, A. (2003). Endothelial dysfunction. A marker of atherosclerotic risk. Arterioscler. Thromb. Vasc. Biol., 23 (2), $168-175$

Ceconi, C., Ferrari, R., Bachetti, T., Opasich, C., Volterrani, M., Colombo, B., Parinello, G., Corti, A. (2002). Chromogranin A in heart failure: A novel neurohumoral factor and a predictor for mortality. Eur. Heart J., 23 (12), 967-974.

Chow, C. T. L., Chow, M. S. S., Anderson, R. H., Gosling, J. A. (2001). Autonomic innervation of human cardiac conduction system: Changes from infancy to senility - an immunohistochemical and histochemical analysis. Anat. Rec., 264 (2), 169-182.

Cihakova, D. (2018). Interleukin-10 stiffens the heart. J. Exper. Med., 215 (2), 379 .

Daka, B., Olausson, J., Larsson, C. A., Hellgren, M. I., Råstam, L., Jansson, P. A., Lindblad, U. (2015). Circulating concentrations of endothelin-1 predict coronary heart disease in women but not in men: A longitudinal observational study in the Vara-Skövde Cohort. BMC Cardiovasc. Disord., 15, 146.

Dashkevich, A., Lemström, K. B., Nykänen, A. I. (2013). VEGF receptor signaling in the cardiac lymphatics. In: The Cardiac Lymphatic System, pp. 125-143.

https://link.springer.com/chapter/10.1007/978-1-4614-6774-8_9 (accessed 10.05.2021)

Davenport, A. P., Hyndman, K. A., Dhaun, N., Southan, C., Kohan, D. E., Pollock, J. S., Webb, D. J., Maguire, J. J. (2016). Endothelin. Pharmacol. Rev., 68 (2), 357-418.

Dhople, V., Krukemeyer, A., Ramamoorthy, A. (2006). The human betadefensin-3, an antibacterial peptide with multiple biological functions. Biochimica et Biophysica Acta - Biomembranes, 1758 (9), 1499-1512.

Di Paolo, N. C., Shayakhmetov, D. M. (2016). Interleukin $1 \alpha$ and the inflammatory process. Nature Immunol., 17 (8), 906-913.

Goel, S. S., Ige, M., Tuzcu, E. M., Ellis, S. G., Stewart, W. J., Svensson, L. G., Lytle, B. W., Kapadia, S. R. (2013). Severe aortic stenosis and coronary artery disease - implications for management in the transcatheter aortic valve replacement era: A comprehensive review. J. Amer. Coll. Cardiol., $62(1), 1-10$.
Goetze, J. P., Alehagen, U., Flyvbjerg, A., Rehfeld, J. F. (2013). Making sense of chromogranin A in heart disease. The Lancet Diabetes and Endocrinology, 1 (1), 7-8.

Goetze, J. P., Christoffersen, C., Perko, M., Arendrup, H., Rehfeld, J. F., Kastrup, J., Nielsen, L. B. (2003). Increased cardiac BNP expression associated with myocardial ischemia. The FASEB Journal: Official Publication of the Federation of American Societies for Experimental Biology, 17 (9), 1105-1107.

Huang, W., Boyle, N., Vaseghi, M. (2017). Cardiac innervation and the autonomic nervous system in SCD. Card. Electrophysiol. Clin., 9 (4), 665-679.

Hulsmans, M., Sager, H. B., Roh, J. D., Valero-Muńoz, M., Houstis, N. E., Iwamoto, Y., Sun, Y., Wilson, R. M., Wojtkiewicz, G., Tricot, B., et al. (2018). Cardiac macrophages promote diastolic dysfunction. J. Exper. Med., 215 (2), 423-440.

Isner, J. M., Chokshi, S. K., Defranco, A., Braimen, J., Slovenkai, G. A. (1990). Contrasting histoarchitecture of calcified leaflets from stenotic bicuspid versus stenotic tricuspid aortic valves. J. Amer. Coll. Cardiol., 15 (5), 1104-1108

Iung, B., Baron, G., Butchart, E. G., Delahaye, F., Gohlke-Bärwolf, C., Levang, O. W., Tornos, P., Vanoverschelde, J. L., Vermeer, F., Boersma, E., Ravaud, P., Vahanian, A. (2003). A prospective survey of patients with valvular heart disease in Europe: The Euro Heart Survey on Valvular Heart Disease. Eur. Heart J., 24 (13), 1231-1243.

Jeong, D. S., Sung, K., Kim, W. S., Lee, Y. T. (2014). Fate of functional tricuspid regurgitation in aortic stenosis after aortic valve replacement. $J$. Thorac. Cardiovasc. Surg., 148 (4), 1328-1333.

Kanwar, A., Thaden, J. J., Nkomo, V. T. (2018). Management of patients with aortic valve stenosis. Mayo Clinic Proc., 93 (4), 488-508.

Lindman, B. R., Clavel, M.-A., Mathieu, P., Iung, B., Lancellotti, P., Otto, C. M., Pibarot, P. (2016). Calcific aortic stenosis. Nat. Rev. Dis. Primers, 2 , 16006

Maeda, S., Tanabe, T., Miyauchi, T., Otsuki, T., Sugawara, J., Iemitsu, M., Kuno, S., Ajisaka, R., Yamaguchi, I., Matsuda, M. (2003). Aerobic exercise training reduces plasma endothelin-1 concentration in older women. $J$. Appl. Physiol., 95 (1), 336-341.

Mann, D. (2012). Pathophysiology of heart failure. In: Publication Veterinary Continuing Education, Massey University, pp. 1-26.

Molenaar, P., O’Reilly, G., Sharkey, A., Kuc, R. E., Harding, D. P., Plumpton, C., Gresham, G. A., Davenport, A. P. (1993). Characterization and localization of endothelin receptor subtypes in the human atrioventricular conducting system and myocardium. Circul. Res., 72 (3), 526-538.

Mosser, D. M., Zhang, X. (2008). Interleukin-10: New perspectives on an old cytokine. Immunol. Rev., 226, 205-218.

Nakagawa, Y., Nishikimi, T., Kuwahara, K. (2019). Atrial and brain natriuretic peptides: Hormones secreted from the heart. Peptides, 111, 18-25.

Novo, G., Sansone, A., Rizzo, M., Guarneri, F., Pernice, C., Novo, S. (2014). High plasma levels of endothelin-1 enhance the predictive value of preclinical atherosclerosis for future cerebrovascular and cardiovascular events: A 20-year prospective study. J. Cardiovasc. Med., 15 (9), 696-701.

Otto, C. M., Kuusisto, J., Reichenbach, D. D., Gown, A. M., O’Brien, K. D. (1994). Characterization of the early lesion of 'degenerative' valvular aortic stenosis. Circulation, 90 (2), 844-853.

Pilmane, M., Rumba, I., Sundler, F., Luts, A. (1998). Patterns of distribution and occurrence of neuroendocrine elements in lungs of humans with chronic lung diseases. Proc. Latvian Acad. Sci., Section B, 52, 144-152.

Sahinarslan, A., Vecchio, F., Maccarthy, P., Dworakowski, R., Deshpande, R. (2016). Dynamics of concomitant functional mitral regurgitation in patients with aortic stenosis undergoing TAVI. Acta Cardiol. Sin., 32 (4), $477-484$.

Schröder, J. M., Harder, J. (1999). Human beta-defensin-2. Int. J. Biochem. Cell Biol., 31 (6), 645-651. 
Selsted, M. E., Ouellette, A. J. (2005). Mammalian defensins in the antimicrobial immune response. Nature Immunol., 6 (6), 551-557.

Shubeitas, H. E., Mcdonough, P. M., Harris, A. N., Knowlton, K. U., Glembotskill1, C. C., Browns, J. H., Chien, K. R. (1990). Endothelin induction of inositol phospholipid hydrolysis, sarcomere assembly, and cardiac gene expression in ventricular myocytes. J. Biol. Chem., 265 (33), 20555-20562.

Stewart, B. F., Siscovick, D., Lind, B. K., Gardin, J. M., Gottdiener, J. S., Smith, V. E., Kitzman, D. W., Otto, C. M. (1997). Clinical factors associated with calcific aortic valve disease. J. Amer. Coll. Cardiol., 29 (3), 630-634.

Sziksz, E., Pap, D., Lippai, R., Béres, N. J., Fekete, A., Szabó, A. J., Vannay, Á. (2015). Fibrosis related inflammatory mediators: Role of the IL-10 cytokine family. Mediators Inflamm., 2015, 1-15.
Tota, B., Angelone, T., Cerra, M. C. (2014). The surging role of Chromogranin A in cardiovascular homeostasis. Frontiers Chem., 2, 1-13.

Travin, M. I. (2017). Current clinical applications and next steps for cardiac innervation imaging. Curr. Cardiol. Rep., 19 (1), 28084596.

Wilkins, E., Wilson, L., Wickramasinghe, K., Bhatnagar, P., Leal, J., Luengo-Fernandez, R., Burns, R., Rayner, M., Townsend, N. (2017). European Cardiovascular Disease Statistics 2017. European Heart Network, Brussels. 192 pp.

Yasushi Matsuzawa, A. L. (2015). Endothelial dysfunction and coronary artery disease: Assessment, prognosis and treatment. Coron. Artery Dis., 25 (8), 713-724.

Zimna, A., Kurpisz, M. (2015). Hypoxia-inducible factor-1 in physiological and pathophysiological angiogenesis: Applications and therapies. Biomed Res. Int., 2015, 549412.

Received 7 November 2019

Accepted in the final form 23 February 2021

\section{HOMEOSTĀZI REGULĒJOŠIE FAKTORI, INERVĀCIJAS, IŠĒMIJAS UN IEKAISUMA MARKIIERI LABĀ PRIEKŠKAMBARA AUDOS PACIENTIEM AR DEĢENERATĪVU AORTĀLĀ VĀRSTUL̨A STENOZI UN KORONĀRO SIRDS SLIMĪBU}

Gan koronārai sirds slimībai (KSS), gan deǵeneratīvai aortālā vārstuḷa (AoV) stenozei ir kopīgi līdzīgi attīstības riska faktori — vecums, paaugstināts zema blīvuma holesterīna līmenis asin̄̄s, cukura diabēts, smēkēěsana, paaugstināts asinsspiediens, iekaisums un metabolais sindroms. Tomēr ne vienmēr šìs slimības tiek novērotas abas reizē, un tas apstiprina katrai slimībai specifisku riska un patoǵenēzes faktoru esamību. Šì pētījuma mērḳis ir noteikt apoptozes, homeostāzi regulējošo faktoru, inervācijas, išēmijas un iekaisuma marķieru izplatību labā priekškambara audos koronāras sirds slimības un deǵeneratīva aortālā vārstuḷa atveres stenozes gadījumos. Plānveida sỉrds operāciju laikā tika paņemti labā priekškambara audu fragmenti no 20 pacientiem ar koronāro sirds slimību un no 9 pacientiem ar deǵeneratīvu aortālā vārstuḷa atveres stenozi. Audu fragmenti tika apstrādāti ar imūnhistoḳīmijas metodi, lai noteiktu ātriju nātrijurētisko peptīdu (ANUP), proteīnu gēnu produktu 9.5 (PGP 9.5), asinsvadu endotēlija augšanas faktoru (VEGF), hromogranīnu A (ChgA), endotelīnu (ET), interleikīnus $1 \alpha$ un 10 (Il-1 $\alpha$ un Il-10), $\beta$ defensīnus 2 un 3 ( $\beta$ D2 un $\beta$ D3). Pastiprināta ANUP produkcija labā priekškambara audos raksturīga gan pacientiem ar KSS, gan pacientiem ar deǵeneratīvu AoV stenozi. ChgA veidošanās labā priekškambara endokarda endotēlija šūnās norāda uz simpātiskās nervu sistēmas aktivitātes regulāciju. Izteiktāka PGP 9.5 saturoša inervācija ir raksturīga pacientiem ar değeneratīvu AoV slimību un sekundāru mitrālā vārstuḷa nepietiekamību. Stabils VEGF pieaugums un endotelīna variācijas bez statistiski nozīmīgas atšķirības liecina par išēmijas ietekmi uz lokālo asins apgādi. Samazināta Il-1 $\alpha$ produkcija kopā ar mērenu vai palielinātu Il-10, $\beta \mathrm{D} 2$ un $\beta \mathrm{D} 3$ produkciju norāda uz lokālās imūnsistēmas dominēšanu pār iekaisumu. 